\title{
Conversa sobre Octavio Paz
}

\section{Celso Lafer e Haroldo de Campos \\ Apresentaçăo de CELSO LAFER}

Em 1984, para celebrar os 70 anos de Octavio Paz, Haroldo de Campos e eu encetamos, instigados por Fernando Mitre, um diálogo estruturado sobre a sua obra que se materializou num texto publicado no Jornal da Tarde de 23/6/84. É este texto que agora esta sendo republicado na Revista USP, para comemorar o Nobel de Literatura de 1990 que Octavio Paz acaba de receber. Ao que esta dito neste dialogo, que mantém, creio eu, sua pertinência, cabe acrescentar duas notas para o leitor interessado.

A primeira, para registrar que a magnıfica transcrição poética de Blanco, por Haroldo, referida no texto do diálogo, foi publicada pela Editora Guanabara em 1986, num belo volume intitulado Transblanco que contém, também, além de outras transcriçōes de Haroldo da poesia de Paz, correspondência e textos sobre o seu percurso poético.

A segunda, para apontar que as mudanças ocorridas no mundo, particularmente depois de 1989, simbolizadas pela queda do Muro de Berlim, foram objeto de uma importante reflexão de Octavio Paz, que acaba de ser publicada com o quevediano titulo Pequeña cronica de grandes dias (México, Fondo de Cultura, 1990).

Entre os destaques que cabe fazer a respeito deste livro, merece menção especial o fato de que aquilo que está ocorrendo corresponde à idéia de Paz sobre a liberdade como o campo do criativo e do inesperado, que se torna consciência ao refletir-se na palavra. Neste sentido, sublinho a sua observação sobre a revisão radical, que hoje caracteriza a URSS, dos princtpios em que se fundamentava o "socialismo real" e que está acontecendo, relembro, no contexto da "sublevação dos particularismos" a que ele fazia referência em Tiempo nublado.

Esta revisão, realçada por Paz, indica a relevância de sua crltica anterior a $\mathrm{El}$ ogro filantropico e a fecundidade de seu estilo de analise politica baseado no método que denominei dos desmascaramentos sucessivos. $E$ neste contexto que também se insere a sua discussão sobre as mudanças da postura mexicana e do seu processo de modernização, que obedece ao dialogo que caracteriza a obra de Paz, entre o geral e o particular, no jogo das conjunçōes e disjunçōes dos signos em rotação, sempre animado, reitero eu, por uma vocação libertária e não-conservadora, que é inerente à sua sensibilidade de poeta e ao não-convencionalismo do seu pensamento.

HAROLDO DE CAMPOS: Devo à sua mediação o meu contato inicial com Octavio Paz, contato que, com o tempo, converteu-se em troca de cartas e amizade pessoal. Pois bem. Recordo-me que, quando você me falou do interesse de Paz pela poesia con-
CELSO LAFERé professor de Filosofia e Teoria Geral do Direito da Faculdade de Direito do Largo de São Francisco (USP), e autor de A reconstrução dos direitos humanos - um diálogo como pensamento de Hannah Arendt (Companhia das Letras). O crédito de HAROLDO DE CAMPOS se encontra no ińcio desta seção. 
creta brasileira e me propôs que eu traduzisse para o português poemas de Octavio, você vinha de uma estada em Cornell, onde fora aluno e se fizera amigo do poeta de $L i$ bertad bajo palabra. Como se deu este seu encontro americano com Paz, numa época em que você (é verdade que sempre vinculado a interesses pela literatura e pela cultura num sentido amplo) escrevia uma tese doutoral bastante específica, uma abordagem jurídico-político-econômica do Programa de Metas do Governo Juscelino. Como combinou as duas coisas e em que medida Paz respondia a suas preocupações teóricas e críticas daquele momento?

CELSO LAFER: Quando soube, em Cornell, que Paz daria um curso no primeiro semestre de 1966, fiquei altamente interessado. Eu tinha lido, com entusiasmo, $O$ labirinto da solidão e conhecia algo de sua poesia. Na primeira entrevista que tivemos, necessária para aceitação no curso, $\mathrm{Paz}$, ao saber que eu era um aluno de pós-gradução em Ciência Política, foi logo me dizendo que o seu curso iria tratar da poesia do simbolismo aos nossos dias e que, portanto, a política stricto sensu não iria ser examinada. Respondi que estava ciente, mas que queria fazer o curso da mesma maneira, pois o assunto me interessava. Fui aceito e devo dizer que, para os meus orientadores do Departamento de Governo, esta escolha e esta matéria, no meu currículo escolar, sempre pareceram um tanto estranhas. Não era, no entanto, uma escolha externa às minhas preocupações.

Eu tinha escrito, antes de ir para os Estados Unidos, como parte de minha passagem incompleta pelo Curso de Letras da Faculdade de Filosofia, Ciências e Letras da USP, um pequeno livro - O judeu em Gil Vicente (1963) - e um longo ensaio sobre "O problema dos valores n'Os lusíadas" (1965). Nestes dois trabalhos tentei, de um lado, seguindo a lição de Antonio Candido, analisar a função exercida pela realidade social, historicamente localizada, na constituição da épica camoniana e de um aspecto do teatro de Gil Vicente; de outro, num caminho inverso, porém complementar, busquei descobrir elementos básicos, explicativos da sociedade, a partir da obra literária. Estava portanto ciente de que a literatura também se oferece como um texto, aberto à leitura, de interesse político.

Por outro lado, eu tinha acabado de completar, no semestre anterior, o curso de Hannah Arendt sobre "Experiências políticas do século XX". Neste curso, a exemplo do que fizera em As origens do totalitarismo -, quando examinou o anti-semitismo moderno também através de uma análise dos romances de Disraeli e da obra de Proust, ou o imperialismo europeu também com um apoio numa literatura da ficção de Joseph Conrad -, Hannah Arendt valeu-se, nas suas aulas, das artes e da literatura. Poemas de Brecht e de Rene Char, romances de Faulkner, Hemingway, Ernst Jünger, Malraux, Sartre e Thomas Mann, a pintura de Picasso, Bracque e Matisse foram por ela utilizados para fundamentar uma reflexão sobre o problema da ruptura entre o paśsado e o futuro, que caracteriza a experiência política do mundo contemporâneo. Estava, portanto, naquela ocasião, mais do que convencido que o curso que eu pretendia fazer com Paz haveria de ser um curso aberto ao que está além dos próprios confins, suscetível de também esclarecer as relações entre o ângulo interno da obra literária e o ângulo externo que a abrange e circunscreve.

Evidentemente, não me decepcionei. O curso de Paz antecipava, de certa maneira, o que ele posteriormente discutiu, de forma mais acabada, em Los hijos del limo (1974), no qual, a partir da perspectiva de um poeta hispano-americano, procurou descrever o movimento poético moderno e suas controvertidas relações com o que se chama modernidade, ou seja, o racionalismo e o progresso. Daŕ, na poesia moderna, o diálogo contraditório com e contra as revoluções modernas e as religiōes cristãs; a tentação política e a religiosa; a interação entre analogia e ironia; a esperança e a desesperança, na visão do universo como um sistema de correspondências.

Esta reflexão de Paz sobre a experiência poética guarda correspondência, no meu modo de ver, com suas anteriores análises da experiência política. Refiro-me ao Labi-

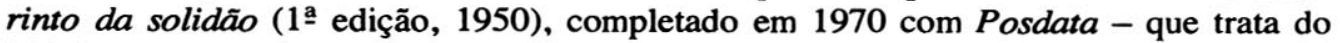
México - e também a Corriente alterna (1 $1^{\text {a }}$ edição, de 1967) -, um mosaico de fragmentos e insights sobre o atual - nas palavras de Sebastião Uchoa Leite -, que, ao se inserir na corrente vital do espírito moderno, lida tamberm com a política.

HAROLDO DE CAMPOS: Em seu ensaio pioneiro sobre o pensamento político de Octavio Paz ("o poeta, a palavra e a máscara"), publicado no livro que, depois, organizamos conjuntamente para a Editora Perspectiva (Signos em rotaçẫo, 1972), você fala 
da "metodologia de desmascaramentos sucessivos", como a característica do modus operandi da reflexão de Paz sobre temas políticos. Ademais, você compara essas "máscaras em movimento" com os signos em rotação da poética de Paz. Como você vê agora, sobretudo à luz das publicações posteriores de Paz, essa caracterização metódica, que parece envolver uma passagem da reflexão poética para a reflexão política e que, antes de mais nada, tem em conta a "ordem do simbólico" quando enfoca o político (para valer-me de uma expressão de Claude Lefort), sem vincular-se a uma visão determinista, econômico-social, da história. Em que medida a heurística do pensamento poético pode fecundar a reflexão polf́tica?

CELSO LAFER: No meu estudo, que é de 1970, procurei explicitar como a reflexão de Paz sobre a poesia era um ponto de partida de uma metodologia de análise política - uma metodologia que começa com a gramática e o restabelecimento dos significados. Com efeito, é através da linguagem. já que o pacto lingüístico antecede o Contrato Social, como dizia Rousseau, que se pode alcançar a chave dos significados, explicativos de uma dada sociedade. Uma explicação que é complexa, pois os signos aparecem num nível mais visível em forma de máscaras, uma vez que os poderosos concebem a história como espelho e vêem no rosto dos outros o aparente esplendor do próprio. Daí o esforço de Paz em buscar, através dos desmascaramentos sucessivos, o perfil de uma sociedade (no caso, a mexicana) e a figura do mundo. Estudos e livros de Paz posteriores a 1970 ampliaram o leque e a abrangência de sua análise política. Destaco particularmente $\mathrm{El}$ ogro filantropico (1979) e Tiempo nublado (1983), que,

Não é possível compreender a modernidade (democracia, técnica, laicismo, etc.) sem lidar com o Estado. É isso que Paz expõe tão bem em "El ogro filantropico", apoiado numa metodologia de desmascaramentos sucessivos (CL) penso eu, comprovam a fecundidade de seu método. Um método cujas características tentei desvendar mostrando como se integrava, já naquela época em que fui aluno de Paz, no conjunto de sua obra. Por isso, ontem

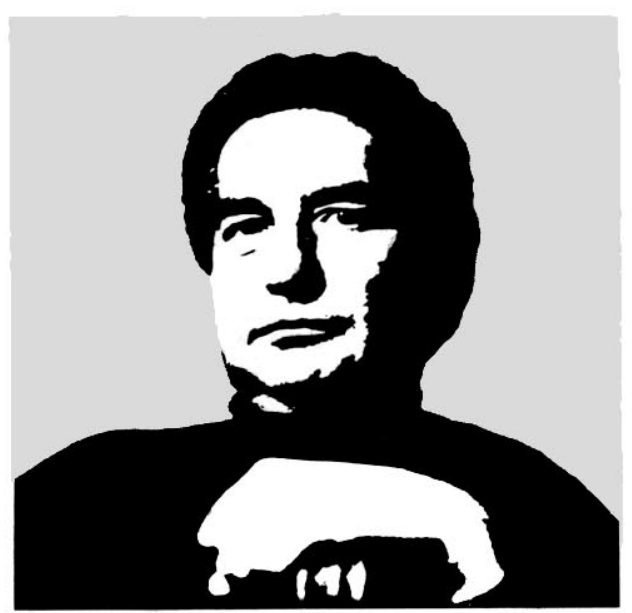
como hoje, ele continua presente no horizonte de minhas preocupações, pois sua admirável obra responde não sơ ao meu interesse pela literatura e pela cultura num sentido mais amplo como também às minhas inquietações analíticas no campo da reflexão política.

De fato, a tradição da análise política, que remonta a Platão e alcança Marx e o funcionalismo, é responsável por uma espécie de dualismo ontológico que hierarquiza, separando, de um lado, o mundo do Ser e da Verdade e, de outro, o mundo do Fenômeno e da Aparência. Para esta tradição, nas suas múltiplas vertentes, todos os fenômenos são vistos como epifenômenos. Por isso, sć podem ser apreendidos como a expressão de algum universal. É claro que esta postura freqüentemente leva a distor-

ções, que obliteram a percepção daquilo que efetivamente está ocorrendo, impedindo que o analista capte a dimensão do concreto que caracteriza a praxis humana. Penso que a metodologia dos desmascaramentos sucessivos, como a característica do modus operandi, da reflexão política de Paz, impede-o de cair, precisamente, neste tipo de obnubilamento, comum na tradição do dualismo ontológico.

Exemplifico: o capitalismo liberal imaginava que o desenvolvimento da livre empresa permitiria o florescimento da sociedade civil e, por isso, a função do Estado reduzirse-ia à de um simples supervisor da evolução espontânea da humanidade. Os marxistas,

Dezembro 
por outro lado, pensavam que o advento do socialismo significaria o aparecimento de uma sociedade auto-regulada, que assinalaria o desaparecimento do Estado. Estas duas máscaras - o capitalismo liberal e o marxismo na sua formulação genérica - são cristais deformantes que tendem a obliterar o fato que a grande realidade do século XX é o Estado, cuja sombra cobre o planeta. O Estado moderno é uma máquina, mas uma máquina que se reproduz sem cessar. Não é possível compreender a modernidade (a democracia, a técnica, o laicismo, etc.) sem lidar com o Estado. É isso que Paz expõe tão bem em El ogro filantropico (1979), apoiado na sua metodologia de desmascaramentos sucessivos, aberta para o fenômeno da ruptura dos universais abstratos, graças à heurística do poético.

HAROLDO DE CAMPOS: E como operaria essa "heurística do poético" na análise do fenômeno político? Como Paz lida

Diria que "Tiempo nublado"

está para a reflexão

política de Octavio Paz

assim como "Los signos en

rotación" está para sua

reflexão poética: num e

noutro o poeta redescobre

a figura do mundo na

dispersão dos fragmentos (CL) com a dimensão ideológica do signo?

CELSO LAFER: Um dos grandes méritos da ensaística de Paz é o de explorar as relações de afinidade e oposição entre os signos. Em Conjunciones $y$ disjunciones (1969), por exemplo, ele examina como cada sociedade tem a sua maneira própria de conceber a relação entre corpo (matéria, natureza) e não-corpo (alma, espírito, mente). Daí a sua instigante reflexão sobre a temperatura das civilizações na análise do tantrismo e do protestantismo, do budismo e do cristianismo medieval. Pois bem: um dos problemas centrais da política contemporânea é o da relação de afinidade e oposição do mundo como um todo e de cada sociedade em particular com a modernidade.

Com efeito, a modernidade, permeada pela máquina do Estado, nas suas múltiplas vertentes, é sem dúvida um fenômeno universal. Tem, no entanto, distintas conseqüências e características de sociedade para sociedade, que os cristais deformantes dos universais abstratos - tais como o capitalismo, o comunismo, o subdesenvolvimento - não captam adequadamente.

A China, o Vietnã, a Índia, o Japão e a América Latina têm processos específicos de recepção da modernidade, seja ela capitalista, seja ela socialista. A Polônia integra o bloco comunista europeu, mas a sua propensão específica à liberdade a diferencia da Alemanha Oriental. O Terceiro Mundo é antes uma nebulosa do que uma unidade. É, no entanto, uma nebulosa de sublevação no plano internacional. Essa sublevação de particularismos o que tem em comum e o que tem de específico? $O$ que significa a ressurreição, no Irã, do primado religioso

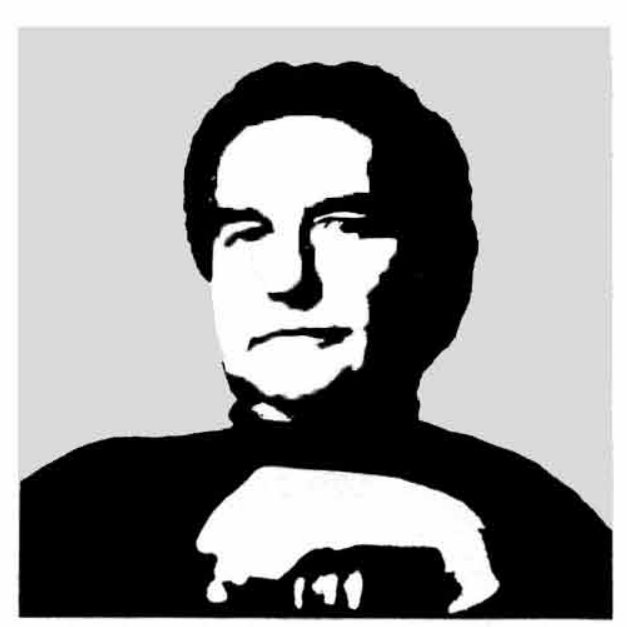
dos aiatolás? Por outro lado, o que caracteriza hoje o Velho Mundo, a Europa Ocidental? Por que existe uma simetria inversa na evolução dos grandes partidos comunistas europeus (da Itália, da França e da Espanha) e a dos terroristas? O niilismo e o hedonismo, que caracterizam a Europa do Mercado Comum, permeiam todas as sociedades capitalistas liberais desenvolvidas? Os Estados Unidos são uma democracia imperial que descobriu que está, depois do Vietnã e de Watergate, em decadência - algo como a divindade dos teólogos, ou seja, indefinível. Oscila, por isso mesmo, entre Epicuro e Calvino. Teria, por isso, perdido a faculdade de orientar-se na história? Por que a União Soviética é um gigante Polifemo a cuidar dos seus rebanhos, condenada simultaneamente a mudanças e à imobilidade, e não um 
Estado obreiro? Quais são, na América Latina, as (des)venturas da democracia?

Esses são alguns dos temas de Tiempo nublado (1983), o último livro de Octavio Paz, recentemente resenhado aqui no Jornal da Tarde (14/2/84) com empatia e inteligência por Gilberto de Mello Kujawski. Entendo que as respostas que oferece Octavio Paz são da maior importância e vejo neste livro uma correspondência metodológica, uma relação de afinidade com Los signos en rotación (que é de 1966 e que depois foi inserido, como novo epflogo, na 2 a edição de El arco y la lira (1967).

Diria que Tiempo nublado está para a reflexão política de Paz assim como Los signos en rotación está para a sua reflexão poética: num e noutro, o poeta redescobre a figura do mundo na dispersão dos fragmentos. É a mesma metodologia que permite a $\mathrm{Paz}$ recuperar, nas suas análises, a pluralidade dos significados que usualmente se escondem atrás da máscara dos universais, num processo que permite entreabrir as diversas faces da realidade. Para isso contribui decisivamente, sem dúvida, a experiência do poeta que lida constantemente com o genérico - a linguagem que $\varepsilon$ social e objetivamente dada e o específico - a criação poética, que procura devolver ao signo a pluralidade de seus significados. Neste sentido, diria, sem dúvida, que em $\mathrm{Paz}$ a heurística do poético fecundou a reflexão política.

A heurística da poética, no entanto, não leva necessariamente à da política. É o caso, por exemplo, de Cummings e Wallace Stevens, para dar dois nomes de poetas que são tanto do seu agrado, Haroldo, quanto do agrado de Octavio Paz. Mas já falei muito. Creio que é o momento de instaurar o diálogo, que proponho, Haroldo, na forma de uma pergunta, ligada a esta separação do poético e do político:

Grandes poetas normalmente não são grandes pensadores - grandes pensadores não tendem a ser grandes poetas. Esta disjunção entre poesia e pensamento não é o que se verifica em Octavio Paz, que reúne na sua trajetória intelectual as virtudes de um poeta e os dotes de um pensador. Qual é o significado desta conjunção - para usar um termo caro a Octavio Paz - de poesia e pensamento? Explicito-me: Carlos Drummond de Andrade e João Cabral, para citar dois nomes brasileiros dentro do arco geracional de Octavio Paz, são poetas admiráveis, mas não se notabilizaram como pensadores - a prosa de João Cabral é quase inexistente e a de Drummond, ainda que muito interessante, não pretende ser a de um pensador. Por outro lado, grandes poetas, quando escrevem ensaios teóricos, geralmente tratam - e bem - de problemas da criação literária, da crítica, raramente ultrapassando o campo da estética definida num sentido amplo. É o caso, por exemplo, de T. S. Eliot e Ezra Pound, cuja contribuição no domínio da reflexão estética é muito significativa - não sei se tão significativa quanto as respectivas criaçōes poéticas, mas sem dúvida muito significativa. Entretanto, quando Eliot trata da política, sua reflexão, que é a de um conservador, não é inovadora, mesmo no campo conservador. Quanto a Pound, o mínimo que se pode dizer de sua postura política é que foi desastrosa e lamentável. O único nome que me ocorre, de sábia combinação de poeta e pensador, é o de Valéry. Penso, evidentemente, no Valéry que é não apenas um grande poeta e um grande crítico - refiro-me, por exemplo, ao que ele escreveu sobre Mallarmé -, mas também no Valéry que incluiu em Varieté importantes estudos filosóficos e quase políticos e que nos ofereceu em Régards sur le Monde Actuel uma lúcida e premonitória análise da direção do mundo, da história e da Europa. Retornando, portanto, à pergunta, depois desta digressão explicativa do seu alcance: como é que você vê esta conjunção do poeta e do pensador em Octavio Paz? Como proceder - se isto for válido - a uma comparação com outras figuras literárias, no mundo e na América Latina?

\section{Poeta Versus Pensador?}

HAROLDO DE CAMPOS: Em primeiro lugar, eu gostaria de pôr em discussāo a pertinência ou - pelo menos - a universalidade de sua equação. Ela tem uma inegável função "aperitiva": de abrir o debate, de "pro-vocá-lo", até no sentido etimológico desta última palavra. Mas a disjunção poeta versus pensador só me parece cabível dentro de uma concepção que veja na poesia apenas (ou privilegiadamente) o aspecto do exercício da "função emotiva da linguagem", que desterre de seu âmbito tudo aquilo que, envolvendo a "reflexão", o pensamento especulativo, a formulação teórica, possa representar o outro pólo, a atividade "metalingüística", e, pois, empanar a suposta "pureza", a "espontaneidade" do ato poético. Sei que esta não é a sua concepção. A sua admiração por Valéry e Octavio Paz, poetas-críticos por excelência, que você tão bem aproxima, é a melhor prova disto. A oposição poesia-metalinguagem encontra respaldo 
na visão croceana da arte como "lírica" ou "intuição lírica" (Croce censurava o "intelectualismo" de Dante e pretendia destilar do "romance teológico" da Commedia uma presumida "poesia del cuore de Dante", única que lhe parecia válida). Todavia, relativizada e referida ao ambiente brasileiro, sua provocativa equação não deixa de encontrar um critério de pertinência. Entre nós, em muitas áreas, vige ainda a idéia do poeta "inspirado", do poeta intuitivo e arrebatado, proveniente do Romantismo que eu chamei "extŕnseco" num ensaio de 1967 ("Romantismo e poética sincrônica") e que Paz, em Los hijos del limo, denomina "exterior e declamatório". Como esse Romantismo extrínseco foi o que predominou no Brasil e, segundo Paz, também na Espanha e na Hispano-América, é natural que a imagem do poeta que dele derivou continue persistente e renitente. Disse, recentemente, numa entrevista, que certa crítica brasileira concebe o poeta como um "curatelado", alguem que, para ser "autêntico", deve resguardar-se num estado parecido ao do "bom selvagem", eternamente afetado de "menoridade", cabendo aos críticos explicar-lhe o sentido de sua atividade, que lhe brotaria com pureza do "coração" e que se turvaria com qualquer exercício de auto-reflexão... Como você sabe, não é esta a grande tradição da poesia moderna, aquela que procede do verdadeiro Romantismo (para não retrocedermos, por exemplo, a Guido Cavalcanti e a Dante, o primeiro deles, poeta-filossofo, embebido de averroísmo, o segundo poeta não apenas encharcado da teologia e da filosofia do seu tempo, mas poeticista, teórico da linguagem e ainda pensador político nos livros da Monarchia). Quando falo no verdadeiro Romantismo, refiro-me àquele que eu chamei "intrínseco", o Romantismo alemão de Iena, dos irmãos Schlegel, de Novalis e, em certa medida, do proprio Hoelderlin (até onde este possa ser considerado um romântico). Na Inglaterra, o correlato desse Romantismo encontra-se em Coleridge (o poeta de Kubla Khan e o crítico da Biographia literaria) e, nos Estados Unidos, num Edgar Allan Poe, o poeta de "The raven", o crftico de "The philosophy of composition", o cosmólogo de "Eureka", o mestre de dois outros grandíssimos poetas-críticos, Baudelaire e Mallarmé, e, através deste, de Valéry. É a essa linhagem de poesia crítica e de poetas-críticos que está dedicado, centralmente, o ensaio de Paz, há pouco mencionado, Los hijos del limo (1974).

Antes do que um caso isolado, Paz filia-se a uma eminentíssima "tradição moderna". (Essa tradição do poeta-pensador poderia ser retraçada por outras vias: como esquecer Goethe e Schiller - o primeiro deles, um verdadeiro exemplo de enciclopedismo poético-filosófico-científico -, na atmosfera do idealismo alemão de Kant, Fichte, Schelling, Hegel? Como não mencionar, na Itália, o Leopardi, poeta-filólogo capaz de renovar, em pauta romântica, o pensamento clássico, cuja continuidade reflexiva no labor copioso do Zibaldone prenuncia a devoção escritural do Valéry dos Cahiers e prepara o Ungaretti poeta e crítico?) Paz, portanto, filia-se a uma tradição, e é dela, hoje, na América Latina e em escala internacional, um dos representantes mais fulgurantes. Mas, em nossa própria América, não poderíamos deixar de mencionar outras grandes figuras de poetas-pensadores, de poetas-críticos. O cubano Lezama Lima, por exemplo, interprete das "eras imaginárias" e do barroco enquanto "arte da contraconquista" e signo por excelência da "expressão americana"; ou então Borges (cuja obra cabe inteira no conceito de "poesia crítica"), encarnação viva da própria Literatura, e cujas idéias - sobre o tempo, a recorrência infinita, a abolição do autor, a relatividade do original e da origem, a "poética da leitura" (como a chamou E. R. Monegal) - ressoaram com tanta força em críticos como Blanchot e Genette ou num filósofo como Foucault.

No Brasil, creio, houve uma interrupção, um hiato geracional, desde o Modernismo e seus nomes exponenciais, Oswald e Mário de Andrade, estes, ambos, marcadamente escritores críticos. Na geração de 30 , que é a que corresponde mais ou menos à de $\mathrm{Paz}$, poder-se-ia citar isoladamente. Murilo Mendes, um homem sempre inquieto, sempre debruçado sobre o novo em poesia, artes plásticas, música, inquieto com a situação do mundo: suas reflexōes críticas tomaram uma forma aforismática, capsular, entrecortada (um pouco na vertente do "Diário" e do fragmento). João Cabral, que prefere fazer metalinguagem no próprio poema - Poesia crítica é o título paradigmal de sua mais recente antologia poética -, ocupou-se esporadicamente da reflexão ensaística (no seu belo texto sobre Miro, nos artigos sobre a "Geração de 45", na tese "Da função moderna da poesia", de 1954). Quando o fez, mostrou-se capaz daquela mesma agudeza e penetração que encontramos em poemas como "Psicologia da composição". Já Drummond, grande poeta, não desenvolveu uma prosa de pensamento, preferindo via de regra a crônica de amenidades (nesse sentido, muito diferente foi Bandeira, patriarca de nosso Modernismo, de quem recordo, por exemplo, uma lucidíssima leitura de Mallar- 


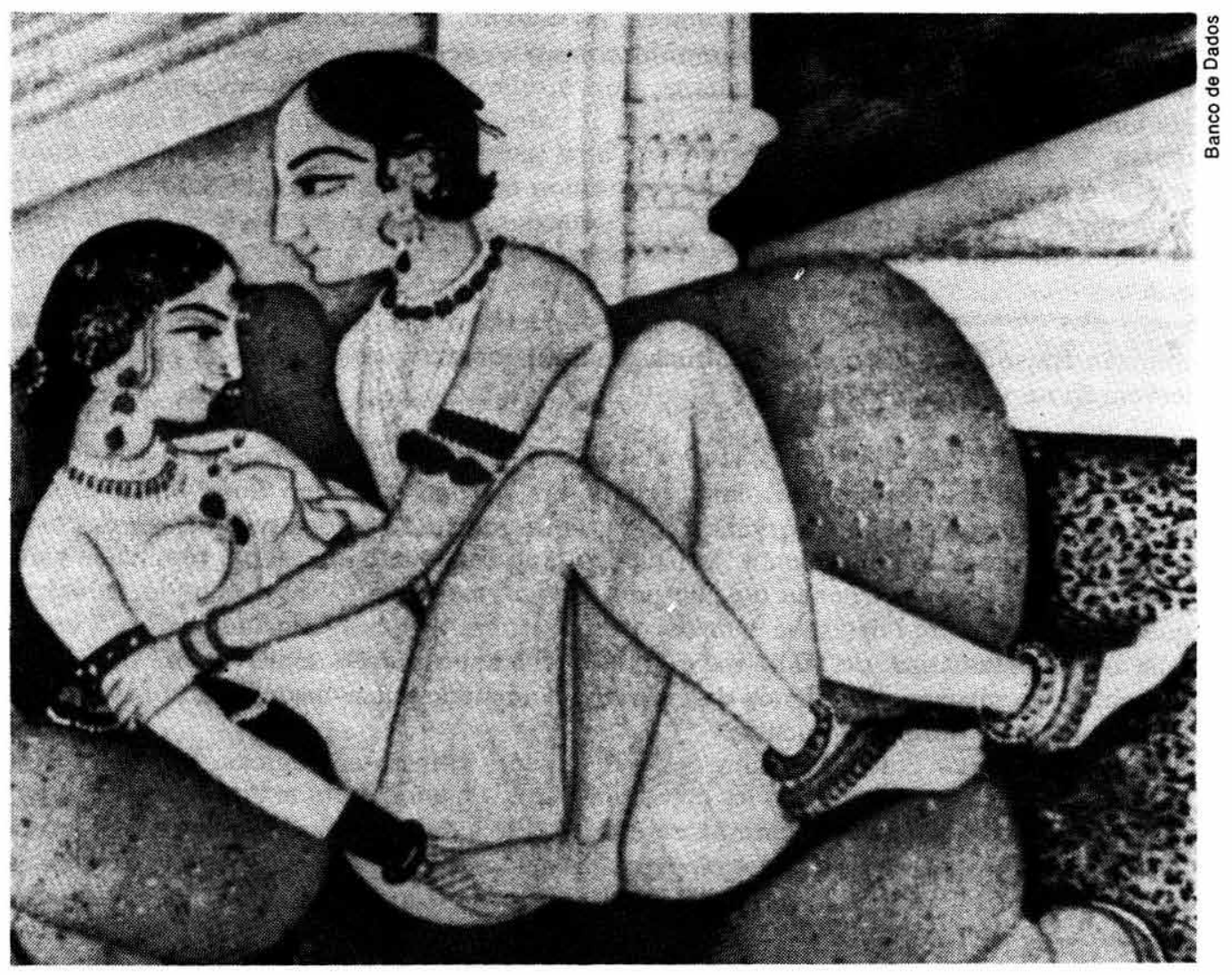

mé, de 1945, incluída em Itinerário de Pasárgada).

A originalidade de Paz, como você muito bem aponta, está na maneira como ele consegue conjugar às considerações sobre poética as reflexões sobre política - inclusive sobre as mais prementes questōes de política atual, mexicana, latino-americana e internacional -, numa série de livros que começa com El laberinto de la soledad (1950) e chega agora a Tiempo nublado (1983). De política e de poesia se ocuparam, com sinais trocados, dois grandes poetas que tiveram destinos trágicos: Ezra Pound, cujos erros dramáticos o arrastaram à prisão e depois ao silêncio, atravessado de arrependimento e amargura; Maiakóvski, cuja paixão por um futuro comunitário e sem burocratas foi uma das causas que o levaram ao suicídio quando começava a maré montante do stalinismo. O primeiro, excessivamente nostálgico do passado (a corporação pré-industrial, a "boa ordem" dantesca ou, mais remotamente ainda, confuciana); o segundo, demasiadamente impaciente do porvir (a comuna ideal, a revolução planetária). Paz escolheu uma via menos passional e mais compatível com a ironia e com a lucidez crítica que ele tanto preza: procura pensar hoje, com clareza pós-utópica, desencantada das totalizações monológicas, o espaço possível, dialógico, de um socialismo com democracia. Nesse sentido, pela via poética (que não é sistemática, mas analógica), as reflexões de Paz, pensador da política, parecem-me estar próximas das de um filósofo da política como Claude Lefort (menciono, por exemplo, um texto de Lefort que acabo de ler, "A filosofia polf́tica diante da democracia moderna"). Entre nós, um ponto de referência a ser repensado no paralelo com Octavio Paz (e com Lezama Lima, na visão do barroco enquanto "estilo das descobertas", avesso ao "egocentrismo ptolomaico" europeu e chave da reinterpretação da Latino América) seria, a meu ver, mais do que ninguém, Oswald de Andrade. O Oswald de A crise da filosofia messianica (1950) e de A marcha das utopias (1953); como também, de algum modo, especialmente com Paz, o Oswald engajado no dia-a-dia da literatura e da política de Ponta de lança (1945).

CELSO LAFER: Foi ótimo que você tivesse aceitado a minha provocação, Haroldo. É claro que eu não dissocio, na poesia, a função emotiva da função reflexiva da linguagem. Camões - que é um dos meus poetas preferidos - $\hat{e}$ outro exemplo da conjunção poesia-metalinguagem, como procurei mostrar, aliás, no meu estudo sobre o pro-
Casal de amantes, miniatura hindu do século XVIII 
blema dos valores n'Os lustadas. Camões, no entanto, como Dante ou Goethe, ê poeta cuja palavra almeja, e num certo sentido consegue, ser totalidade. Não é isso, no entanto, o que ocorre na poesia moderna, pois a relação entre significante, significado e conjuntura tornou-se dilemática. Por isso, a palavra do poeta moderno é antes fragmento do que totalidade. Dar, penso eu, uma parte das dificuldades da relação entre poesia e pensamento. Paz, no entanto, enfrentou com sucesso estas dificuldades. Você diria que isso resulta de um núcleo de inquietações comuns, indentificável no Paz poeta, Paz crítico literário e de cultura, Paz pensador filosófico e político? Como decifrar esta ars combinatoria? Seria o caso de dizer que a insistência na metalinguagem é relevante não só para o fazer poético e crítico de Octavio $\mathrm{Paz}$, mas igualmente para a sua reflexão filosófica e poética, esta última tendo claramente um objetivo de atuação e intervenção na vida pública?

HAROLDO DE CAMPOS: Fui demasiado extenso na resposta à sua primeira questão, o que me permite ser mais breve agora, já que o terreno ficou preparado. $\mathrm{O}$ poeta-pensador não se inclina, via de regra, ao tratadístico, à construção sistemático-linear. Tende antes ao pensamento "prismático", ao fragmento aforístico. Inclina-se mais para a disrupção nietzscheana do que para o logos hegeliano. Nesse sentido, talvez, é que Derrida veja em Nietzsche e na escritura poética "irredutivelmente gráfica", constelar ou ideogramática, de Mallarmé e Pound, uma contribuição decisiva para o "arrombamento" da clausura metafísica da episteme ocidental, linear-discursiva por definição em seu modo de desenvolvimento.

$\mathrm{Paz}$ procede por grandes conjunções e disjunçōes rítmico-analógicas. Poesia e história se interpenetram, se deixam ler como um livro: o mundo é um texto. A analogia, para Octavio Paz, é a chave da leitura desse texto. Ele a define como "o recurso da poesia para fazer frente à alteridade". E completa: "Ao mundo moderno do tempo linear e suas infinitas divisões, ao tempo da mudança e da história, a analogia impõe, não a impossível unidade, mas sim a mediação de uma metáfora". Por outro lado, Paz é o primeiro a reconhecer que "a poética da analogia somente poderia nascer numa sociedade fundada - e roída - pela crítica". Pois sabe que a busca de unidade e de identidade que a analogia postula é constantemente questionada pela negatividade da ironia. "A ironia é a ferida pela qual a analogia se dessangra." Poder-se-ia também dizer - creio - que a ironia é a "consciência infeliz" da analogia... De qualquer modo, o que Paz parece querer captar pela via do método analógico são as vicissitudes do poético na sua sempre renovada (e constantemente frustrada) vocação por encarnar-se no social. Nesse sentido, ele intenta uma poética do político e do histórico. Talvez se possa ver no método analógico, infiltrado de ironia, por meio do qual Paz procura ler, por metáforas, o espaço histórico e lidar com a diferença e com a "outridade", algo de semelhante àquilo que Walter Benjamin procurava fazer com as suas "imagens dialéticas" e seu método "alegórico": as primeiras, um modo de sonhar a história e compeli-la a despertar; o segundo, retomado na acepção etimológica de "dizer o outro" e permanentemente assaltado pela idéia de "ruína"... Penso que as "Teses para a filosofia da História" ("Ueber den Begriff der Geschichte", 1940), do último Benjamin, marxista rabínico e heterodoxo, redigidas com a concisão cabalística de um texto mallarmeano, na sua tentativa de construção não-linear da história a partir da perspectiva messiânica dos oprimidos, poderiam também ser descritas como uma "poética" (no sentido de uma reflexão sobre os "modos de fazer") "da historicidade"... Há, porém, uma diferença de perspectiva: a de Paz, que põe em dúvida, o telos messiânico, o "futuro quimérico", seria antes a perspectiva do presente "oprimido" ou "reprimido", tentando reescrever uma "história plural" e sublevando-se contra os "paraísos geométricos" (sistemas) prometidos pela historiografia linear-progressiva.

Mas voltemos ao poeta Octavio Paz. Sei que você, em carta a Paz, desenvolveu uma interpretação de Blanco, poema que é, para mim, o ponto culminante da produção poética do autor de Signos en rotación; o ponto em que a reflexão teórica sobre o devir da poesia se encarna no próprio poema (a metalinguagem se reencarna em linguagem). Gostaria de ouvi-lo sobre essa sua leitura de Blanco, já que, em 81, eu traduzi esse poema para o português numa operação "transcriadora", a que chamei Transblanco.

CELSO LAFER: A minha leitura de Blanco ecoa e, por assim dizer, responde ao curso que fiz em Cornell com Octavio Paz, em 1966, sobre a teoria e a prática da poesia do simbolismo nos nossos dias. Nesse curso, Paz realçou o tema da cisão entre as pala- 
vras e as coisas no mundo moderno, mostrando as inquietações do poeta ao verificar que a sua palavra viva não coincide com a palavra vivida pela sociedade. $O$ hiato entre o tempo do poeta e o tempo da sociedade, entre o olho do poeta e a dança dos significados, Octavio Paz esclareceu no seu curso de diversas maneiras. Lembro, por exemplo, como ele contrastou os versos longos de Whitman - indicativos de uma confiança na possibilidade da poesia cavalgar a história - e as linhas curtas e quebradas de Pound -, reveladoras de um homem perdido no mundo. Recordo ainda como chamou a nossa atenção seja para a inserção, com Baudelaire, de temas prosaicos na poesia; seja para a dimensão hermética da linguagem de Nerval; seja ainda para a poesia ideogramática de Apollinaire. Todas essas análises eram indicativas, para Paz, da dissolução da analogia clássica a respeito da conexão entre as palavras e as coisas. Isso o levava à conclusão de que a poesia moderna é não apenas expressão, mas igualmente experimento - um experimento revelador das dificuldades e dilemas do poeta, ao verificar a erosão do seu poder e de sua possibilidade de nomear as coisas. Foi aliás neste contexto - ao discutir, a partir de Mallarmé, a forma fechada dos padrões recorrentes e a forma aberta, na qual o acaso incorpora o leitor - que ele falou da poesia concreta.

Pois bem: ao ler Blanco, em 1968, escrevi a Octavio Paz, no encadeamento de uma digressão sobre as implicações políticas da distinção entre palavra falada e escrita, e o que ensejava para a análise da seriedade da palavra e a seriedade da ação, o seguinte: “... creio que se pode partir da distinção formulada por Auerbach em Mimesis, na qual ele marca as duas formas antitéticas da representação da literatura ocidental, a seriedade bíblica e o Iudus homérico. Vale dizer, o modelo e o jogo. A sua concepção de poesia em grande parte, porém não exclusivamente, se integrava na vertente da seriedade bíblica, pois a experiência poética é descrita na $1^{\text {a }}$ edição de $O$ arco e a lira como uma experiência reveladora da condição humana - o ser jogado, o estar aí -, experiência essa que é recriada pela imagem que capta a dualidade e o contraditório, o ser e o nada, e que nos aproxima desta forma de verdade. Esta reflexão encontra uma 'presentación' anterior, para usar os seus termos, no poema 'Escritura', de Puerta condenada, e uma comprovação por exemplo em Piedra del sol. Por outro lado, os seus poemas, que são uma reflexão sobre o poema, por exemplo, certos poemas breves e 'Trabajos del poeta', e suas reflexões em Signos en rotación correspondem à vertente homérica na medida em que a consciência da ambigüidade do ser provoca a ironia lúdica".

Depois destas observações, acrescentei alguns comentários a respeito da distinção entre a seriedade do discurso e a ambivalência do diálogo, que tinham a sua raiz na primeira aula do curso que Paz dera em Cornell, quando falou do significado do silêncio em Wittgenstein; da tirania de um só significado na reforma da linguagem na velha China e da anarquia das palavras com muitos significados - assuntos que hoje me fazem lembrar Hobbes, quando este aponta o papel do poder na unificação dos significados como antídoto para a anarquia da linguagem no subjetivismo do estado de natureza para, afinal, concluir que Blanco representava uma admirável combinação das duas vertentes, a bíblica e a homérica, apontadas por Auerbach - “o modelo e o jogo". Daí, no meu entender, a importância de Blanco, "pois a presença do modelo impede a tautologia e a presença do jogo revela concomitantemente a situação dilemática do modelo",.

Gostaria, agora, de fazer-lhe uma "repergunta". Você está ultimando para publicação, segundo sei, a sua tradução de 1981 de Blanco. Por que, no seu entender, Blanco, que é de 1966, representa um dos momentos mais altos do fazer poético de Octavio Paz? Tendo respondido à sua pergunta a respeito de minha longínqua interpretação de Blanco, gostaria de ouvi-lo um pouco mais sobre este tema, mesmo porque a produção poética de Paz, posterior a 1966, é considerável.

HAROLDO DE CAMPOS: Sua interpretação de Blanco, que eu não conhecia senão pela breve menção que você a ela fizera numa conversa recente, parece-me extremamente lúcida e instigante. De certa forma, ela também explica o porquê do meu duradouro interesse por Blanco, além do fato de que - como "transcriador" de poesia tenho uma particular atração pelo desafio dos poemas difíceis, dados por "intraduzíveis"... Blanco, em meu modo de ver, está para a obra de Paz (que é muito importante no seu todo, que tem um "antes" e um "depois" que me aliciam e me seduzem, e que eu continuo a acompanhar com a mais viva atenção "simpoética" em cada um de seus desdobramentos: - Discos visuales, Topoemas, Renga, Pasado en claro, Vuelta), Blanco está para essa obra como Trilce para a de Vallejo, Altazor para a de Huidobro, En la
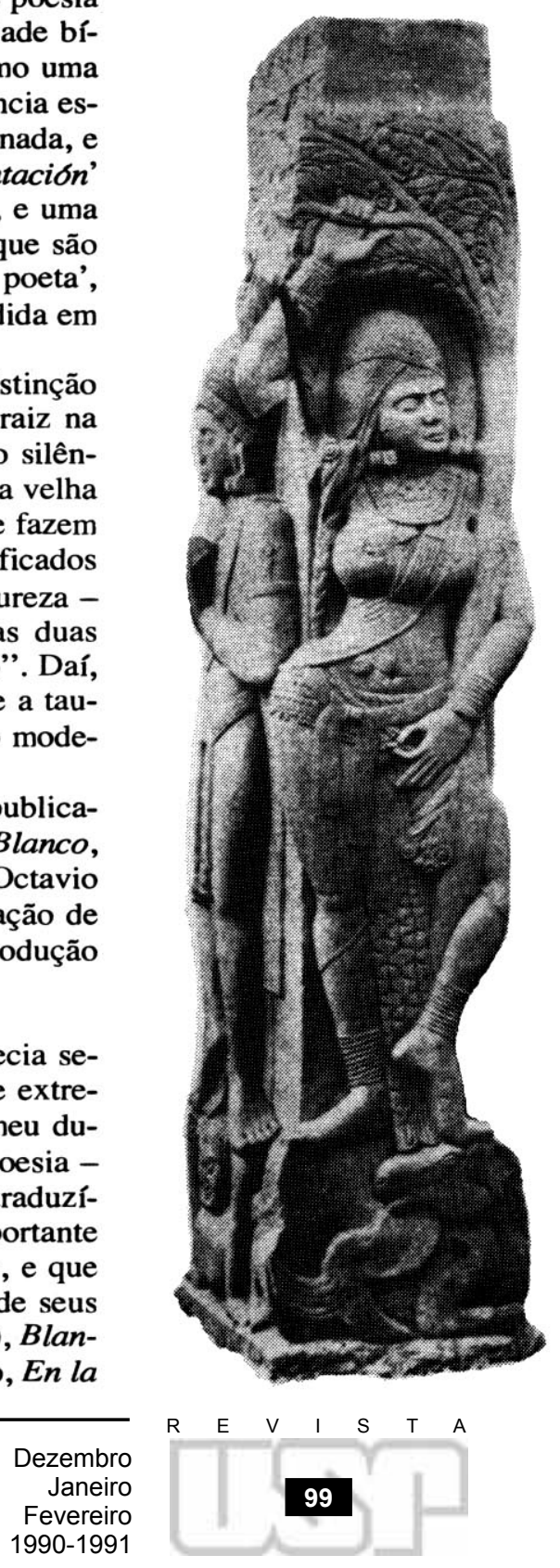
Masmédula para a de Girondo. É, e a meu ver continua sendo, o seu ponto zenital até agora. É a resposta de $\mathrm{Paz}$ ao Lance de dados mallarmaico, uma resposta que se rege não pelo ritmo recursivo da constelação, mas pela dialógica tântrica do SIM e do NẪO, do APARECER e do DESAPARECER, do PLENO e do VAZIO, do texto como corpo e do corpo como texto. Ao contrário de outros poemas longos, tentados no espaço literário latino-americano, Blanco não é a mera acumulação temática de poemas mais curtos, uma soma quantitativa, mas, sim, é pensado qualitativamente como uma "estrutura" - uma estrutura dinâmica, em movimento. MODELO e JOGO, como você sintetiza admiravelmente. Nesse sentido, parece-me muito feliz o poeta e ensaísta húngaro Gyorgy Somlyo (cujo estudo sobre Paz foi recentemente vertido para o português por Nelson Ascher), quando procura ver a poesia de $\mathrm{Paz}$ (e isto se aplica em especial a Blanco) com o auxílio da categoria jakobsoniana da "poesia da gramática", escrevendo: "A poesia de Octavio Paz não se diferencia do modelo surrealista, ou daquele tido por moderno no passado mais próximo, somente através do desprezo pelas imagens tradicionais e mesmo pelas modernas - diferencia-se sobretudo por substituir o pretenso e declarado 'automatismo' da linguagem pela estruturação lingüística diametralmente oposta. Ela expressa, senão tudo, o essencial não com sons, cores e sabores lexicais, mas com nuances de estruturas gramaticais". Essa "matriz combinatória" do poema, no seu jogo permutacional que refuta a lógica analítica em prol da analogia foi surpreendida também pelo poeta e crítico peruano Julio Ortega, em artigo no qual se refere à minha tradução do poema $B l a n c o$, trabalho cujo processo elaborativo ele acompanhou em 81 , durante a minha estada em Austin, na Universidade do Texas. Nada melhor, portanto, do que eu reiterar aqui o que escrevi em 71 e que volto a subscrever hoje: "Nesse poema desdobrável como um livro japonês, visual, de leitura múltipla, a metáfora persiste, porém resgatada da fácil carnadura discursiva, liberta da linearidade da língua, fragmentada, concentrada, pulverizada em estilhaços-concreções. É metáfora e antimetáfora: metáfora que se subleva contra o engaste do discurso, como um diamante amotinado contra sua lavra e redistribuído espacialmente em sistema autárquico de cintilações".

Agora é a minha vez de propor-lhe uma questão. Você é um estudioso de Hannah Arendt, de quem também foi aluno e sobre quem tem escrito com tanta lucidez e penetração. Em que medida, Celso, o "método de desmascaramento", como você designa os diagramas analógicos através dos quais Paz tenta captar e decifrar os signos políticos em movimento -, pode ter algo em comum com a hermenêutica do político que foi desenvolvida por aquela notável pensadora em seus livros, sobre temas, por vezes, bastante afins àqueles tocados pelo fecundo poeta-ensaísta mexicano?

CELSO LAFER: Paz é um poeta que com o correr do tempo foi-se tornando também pensador político, numa passagem da reflexão poética para a reflexão política, que leva em conta a ordem do simbólico na vida pública. Hannah Arendt não foi poeta, ainda que tivesse escrito alguma poesia, como nos revela sua biógrafa Elizabeth Young Bruehl. A poesia, no entanto, foi algo que Hannah Arendt sempre privilegiou. Na história da filosofia política, uma das características da reflexão de Hannah Arendt ê a de também ver a política como uma atividade estética. Aponta, neste sentido, Bhikhu Parekh - num importante livro de 1981; Hannah Arendt and the Search for a New Political Philosophy: ao contrário de Platão, que subsume a política na categoria da "verdade", e diferentemente de Aristóteles, São Tomás, Hobbes, Locke, Bentham, Hegel e outros que subsumem a política no "bom" e no "bem", definidos, é claro, de distintas maneiras, Hannah Arendt subsume a política no "belo". Ela está preocupada em tornar, pela política, o mundo belo, indicando por isso mesmo temas que devem ser considerados na medida em que se possa administrar e controlar o campo da necessidade, ou seja, os problemas econômicos do mundo contemporâneo. A estética, lato sensu, é portanto algo que permeia a vida e a obra, tanto de Paz, quanto de Hannah Arendt, como pude também verificar pelo contato pessoal com ambos. Começo, por isso mesmo, a resposta à sua pergunta com um depoimento pessoal.

Li em Cornell, quando aluno de Paz, "Revolta, revolução e rebelião", texto que ele incorporou em Corriente alterna, que é de 1967, e que nós, aliás, inclứmos na nossa antologia para a Perspectiva. O texto me impressionou e, ao comentá-lo com Paz, mencionei o que Hannah Arendt escrevera sobre o assunto em On Revolution - que eu tinha lido no semestre anterior, quando aluno dela. Paz, que conhecia a obra de Hannah Arendt, mas não On Revolution, ficou surpreendido com algumas das coincidências e afinidades. $\mathrm{O}$ interesse de Paz é compreensível, pois, como nota com acuidade Ramón 
Xirau, revolta, revolução e rebelião são distinções importantes que permeiam, implícita ou explicitamente, toda a obra de Paz. São igualmente distinções importantes para o entendimento da obra de Hannah Arendt.

Hannah Arendt, na linha da filosofia da existência, parte de uma "rebelião" diante da cisão operada por Kant, no que diz respeito à clássica unidade entre ser e pensa'mento. Esta cisão a "revoltou" quando sofreu o impacto do totalitarismo e refletiu sobre o hiato entre o passado e o futuro que caracteriza o totalitarismo, enquanto nova forma de governo e dominação, produto da dissolução des conceitos, categorias e utopias filosófico-político-morais da tradição ocidental. Isso levou-a a pensar na "revolução" - no significado de um novo começo para a política que pudesse restaurar, em termos modernos, a importância grega do espaço público e da liberdade para a dignidade do homem.

Octavio Paz parte igualmente de uma "rebelião" - de uma desobediência indócil diante da percepção moderna que a relação entre ser e sentido é arbitrária e que, portanto, não existe identidade entre a palavra e aquilo que esta designa. Daí a sua "revolta" de poeta - a sua insatisfação, que $\varepsilon$, na linha de toda grande poesia moderna, a partir do pre-romantismo, uma forma de resistir, por não poder aceitar, a incongruência entre o criar (a palavra viva) e as coisas (o viver rotineiro e alienante da civilização contemporânea). Daí o fascínio de Paz pela "revolução", entendida como uma ponte entre a palavra viva e a palavra vivida, reflexão e espontaneidade, fonte possível, "Blanco" é a resposta de Paz ao "Lance de dados" mallarmaico, que se rege não pelo ritmo discursivo da constelação, mas pela dialógica tântrica do Sim e do Não... do Pleno e do Vazio, do texto como corpo e do corpo como texto $(\mathrm{HC})$ mas não necessária, da combinação de ciência e arte. Este fascínio, em Paz, pela revolução, como você disse há pouco, integra "as vicissitudes do poético na sua sempre renovada (e constantemente frustrada) vocação por encarnar-se no social".

Rebelião, revolta e revolução são temas

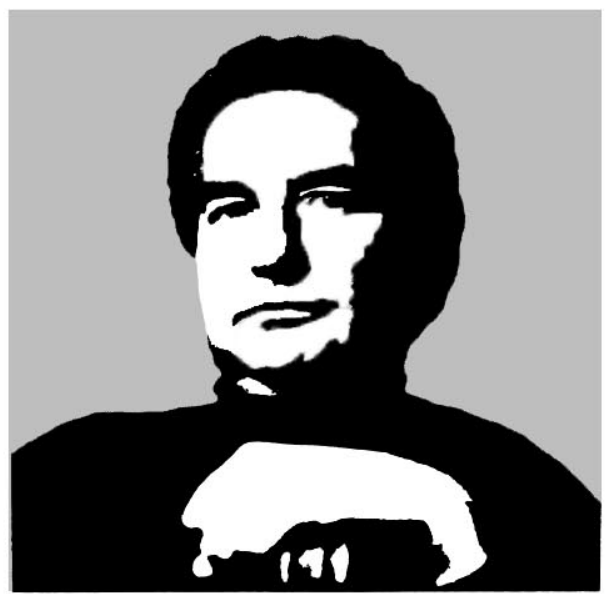
afins a Hannah Arendt e Octavio Paz, porque ambos têm em comum uma preocupação com a "modernidade", vista no seu amplo leque de significados - o cultural, o político, o econômico e o filosófico, etc. Esta preocupação comum com a modernidade traduz-se, em ambos, por um esforço contínuo de não ver os fenômenos da realidade moderna como epifenômenos - como máscaras de "universais abstratos", do tipo capitalismo, comunismo, subdesenvolvimento, etc. Daŕ, tanto num, quanto noutro, a constante garimpagem dos significados. Uma garimpagem orientada pela crítica e pela percepção da crise e aberta para a dimensão do concreto que caracteriza a praxis humana. É por isso que vejo afinidades e complementaridades entre os dois, que não são apenas de atitude. Elas se manifestam na análise, quando se debruçam sobre temas coincidentes. Penso na reflexão de Hannah Arendt sobre a burocracia e nas de Octavio Paz sobre o Estado como um ogro filantrópico; ou então no que diz Hannah Arendt sobre a violência e o que expõe Octavio Paz sobre o terrorismo - temas insuscetíveis de apreensão adequada por meio de "universais abstratos".

Acrescento que tanto Hannah Arendt quanto Octavio Paz acreditam firmemente na possibilidade de pensar pela própria cabeça - no que Lessing, que Hannah Arendt tanto apreciava, chamava de selbstdenken. Por isso, não têm medo do juízo e iluminam, mesmo quando se equivocam, a nossa circunstância, pois possuem ambos a ousada prudência, entendida à maneira de Castoriadis, como a faculdade de orientar-se na história. 
Para concluir: em janeiro de 1972 enviei para publicação na revista Plural, do México, um artigo sobre Hannah Arendt. Paz, que na época dirigia Plural, escreveu-me em fevereiro aceitando o artigo e dizendo: “... conheci em New York, há algumas semanas, Hannah Arendt e me encantou a sua vitalidade como antes me havia conquistado, ao lêla, sua inteligência e retitude filosófica". Vitalidade, inteligência e retitude filosófica são termos igualmente aplicáveis a Octavio Paz. Eles marcam as afinidades eletivas maiores que os unem - afinidades que me permitiram valer-me das palavras de $\mathrm{Paz}$, ao receber o prêmio Jerusalém, para resumir a paidéia arendtiana que quer, à maneira do poeta, que a palavra se encarne no ato livre e a liberdade se torne consciência ao refletir-se na palavra.

\section{Sim, os pontos em comum}

com Paz são numerosos.

Desde logo, o mútuo

interesse pela poesia

japonesa (o "haicai") e

chinesa. $O$ problema da

tradução de poesia, como

coisa fundamental, prática

e teórica... (HC)
Volto agora a perguntar. Numa carta que Octavio Paz me escreveu em 10 de maio do mesmo ano de 1972, dos Estados Unidos, onde ele se encontrava dando cursos na Universidade de Harvard, ele dizia: "Passei quase toda a quarta-feira passada com Haroldo de Campos. Na manhã, fomos à $\mathrm{Bi}$ blioteca Houghton e vimos as provas da edição original de Un coup de dés - aquela edição que Mallarmé concebeu com tanto cuidado e que nunca foi publicada. Vimos as provas corrigidas pelas mãos de Mallarmé e as admiráveis ilustrações de Odilon Redon. Foi muito emocionante. À noite, para coroar este dia inesquecível, jantamos na casa de Roman Jakobson. Libamos imensas quantidades de vodka - aos 70 anos Jakobson bebe como um verdadeiro futurista russo - e ouvimos discos: poemas de Maiakóvski ditos por ele mesmo e a leitura de uma carta de Tolstói aos seus netos, lida ainda que pareça mentira - por Tolstói um ano antes de morrer". Mallarme, Jakobson, Maiakóvski são alguns pontos evidentes de afinidade entre Octavio Paz e você. Quais seriam outros pontos em comum que você gostaria de realçar, neste nosso solo a dos voces sobre e para celebrar os 70 anos de Octavio Paz?

HAROLDO DE CAMPOS: Também me recordo desse dia memorável, em Cambridge... Eu tivera uma pista da existência, na Biblioteca de Harvard, do jogo de provas do Coup de dés com as correções do próprio Mallarmé, isto por via de Robert Greer Cohn, o grande exegeta americano do Lance de dados, professor em Stanford. Fui vê-lo e consultá-lo juntamente com Octavio, já que eu estava preparando a edição brasileira de minha tradução do poema constelar. (Posteriormente, em 1980, Mitsou Ronat e as edições $D^{\prime}$ Atelier restituíram, em sua forma original, o projeto mallarmeano num livro-álbum, de tiragem limitada.) À noite, foi o jantar em casa de Roman Jakobson e Krystyna Pomorska, com os quais eu estava em contato desde 1966 e que haviam visitado o Brasil em 1968. Lembro-me que Jakobson mencionou-me o projeto de analisar um soneto de Quevedo em comparação com um poema quevediano de Octavio (não sei se chegou a levar a cabo essa idéia fascinante). Sim, os pontos em comum com Octavio Paz são numerosos. Desde logo, o mútuo interesse pela poesia japonesa (o "haicai") e chinesa. O problema da tradução de poesia, como questão fundamental, prática e teórica. A maneira de considerar o nacional e o universal em literatura e cultura (detive-me sobre isto num ensaio de 1980, "Da razão antropofágica", por sinal republicado na revista Vuelta). A visão sincrônica do passado literário, que me permitiu - e

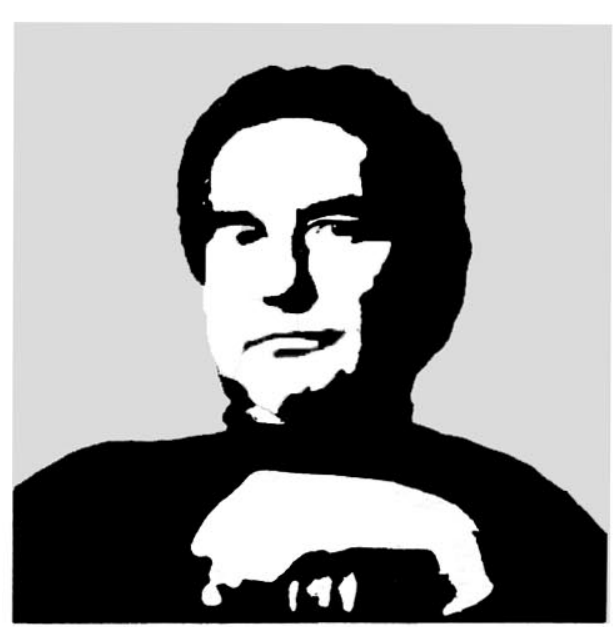


a Augusto de Campos - resgatar Sousândrade do quadro convencional do Romantismo brasileiro e vê-lo, no seu momento culminante, $O$ inferno de Wall Street (cerca de 1870), como precursor da poesia-montagem, polilíngüe e vertiginosa, de Ezra Pound; que permite a Paz ver em Primero sueño, de Sor Juana Inés de la Cruz (uma poeta-pensadora, como ele a define por oposição a Gôngora, de uma "extraordinária inquietude intelectual", de uma "curiosidade enciclopédica"), um "poema do conhecimento", precursor do Lance de dados... Quando Octavio Paz escreve em Los hijos del limo: “... não sou um historiador da literatura (...) Aceito que mel: método possa ser tachado de arbitrário; acrescento que essa arbitrariedade não é gratuita. Meus pontos de vista são de um poeta hispano-americano; não são uma dissertação desinteressada, mas sim uma exploração de minhas origens e uma tentativa de auto-identificação indireta. Estas reflexões pertencem a esse gênero que Baudelaire chamava 'crítica parcial', a única que lhe parecia válida" - sinto que concordo com ele em gênero, número e caso. Tanto assim que na "Nota prévia" a meu livro A operação do texto (1976) remeti-me a essa declaração e associei-a a outra, de Walter Benjamin, extraída de "A técnica do crítico em 13 teses": "Quem não é capaz de tomar partido, deve calar".

\section{a paixão Pelo ensaio Como forma}

Condivido, com Paz, a paixão pelo ensaio como "forma", como "poema intelectual", na bela definição de Schlegel invocada pelo jovem Lukács da "Carta a Leo Popper". Mesmo em meu trabalho mais "estrutural" (no fecundo sentido jakobsoniano do termo, um sentido que Paz sabe tão bem preservar quando faz restrições ao lado dogmático de certo "estruturalismo" francês), mesmo em meu livro de 1973, Morfologia do Macunaíma, não me preocupei apenas em refutar, através da análise detalhada, a renitente acusação de "caoticidade" e "malogro" que se movia à rapsódia andradiana desde João Ribeiro (e que eu suponho ter contribuído para invalidar). Meu particular empenho esteve também - e muito nitidamente - na captação do aspecto "plúrimo" e "cambiante" da obra, na dialética entre o cânon fabular e sua "desagregação", acompanhada através dos dispositivos transgressores do humor e da paródia. A paródia que eu sempre entendi (desde 1967, quando Bakhtin ainda não ecoava entre nós) como um "canto paralelo", na acepção etimológica do termo. Em "O seqüestro do texto ausente" ("Postscriptum" à Morfologia) busquei resolver o detalhismo e o rigor necessários à análise morfológica no "provisório" e no "acidental", ou seja, no modo escritural do ensaio como "fíç̧ão heurística". É aí que intento suscitar (como Paz, a propósito de Sor Juana e de seu sonho piramidal e icárico) a Constelação mallarmaica em conjunção (irônica, "rasurada") com a Ursa Maior macunaímica, metamorfose do "herói capenga", errante interrogação estelar... Como é nesse meu livro goetheanamente "morfológico", numa das notas que deixei proliferar barroca (e prazerosamente) ao longo das radiais mais austeras do organograma de base, que esboço uma proposta de comparação entre as idéias mário-andradianas sobre o brasileiro como "herói descaracterizado" e as de Octavio Paz sobre o mexicano e a "mexicanidade" como "ruptura" e "negação", expostas em "Os filhos da Malinche" (El laberinto de la soledad).

E você, como você vê, Celso (para ficarmos só neste aspecto, que me parece fundamental), o problema das relações entre circunstância latino-americana (a questão do nacionalismo, afinal) e universalismo em Octavio Paz? Reporto-me, por exemplo, a uma colocação como esta, de Puertas al campo (1966): "Desenraizada e cosmopolita, a literatura hispano-americana é regresso e procura de uma tradição. Ao procurá-la, a inventa"... Ou, ainda, à recusa de Paz em aplicar o conceito de "subdesenvolvimento" (segundo ele, um "eufemismo" do economês da ONU...) para caracterizar a literatura de alguns países periféricos: "Não se podem chamar 'subdesenvolvidos' Kavafis, Borges, Unamuno, Reyes, apesar da situação marginal da Grécia, da Espanha e da América Latina".

CELSO LAFER: A relação entre nacionalismo e universalismo, como você diz, Haroldo, em seu arguto e lúcido artigo: "Da razão antropofágica: a Europa sob o signo da devoração", começa quando se pensa a "diferença". O nacionalismo é para você o movimento dialógico da diferença. Este diálogo - ou seja, a dialética do nacional e do universal - como observa Octavio Paz, não pode ser uma simples repetição do repertório universal, porque senão o diálogo se petrifica, e há de ser crítico, senão o diálogo se imobiliza. O risco da petrificação e da imobilização, na dialética nacional-universal,

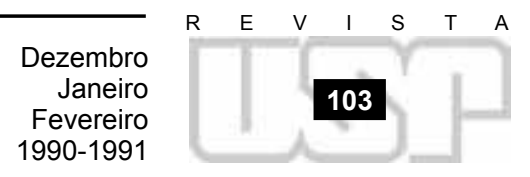


pode ser entendido recorrendo-se a uma observação de Toynbee, ao examinar o encontro de civilizações no espaço. No seu A Study of History, verifica ele dois tipos de respostas judaicas ao helenismo: a "zelotista", que afirmava a particularidade para recusar a cultura grega, e a "herodiana", que recusava a diferença para aceitar o processo de helenização.

Hélio Jaguaribe sugere que a reflexão de Toynbee é heurística para se identificar, através destas duas atitudes, dois modelos alternativos de respostas a culturas expansivas dominantes. Estas duas atitudes podem levar à petrificação ou à imobilização quando o herodianismo não é crítico ou quando o zelotismo não é um autêntico e ilustrado repensar-se. No campo da cultura judaica do século XX, Walter Benjamin e Gershon Scholem são respectivamente dois exemplos paradigmáticos de herodianismo crítico e de zelotismo ilustrado. A amizade e o diálogo que os uniram esclarece como estas duas atitudes podem ser fecundas e complementares na reflexão sobre a modernidade.

Estas duas categorias são evidentemente "tipos ideais" e comportam interpretações, qualificações e complementaridades. Exemplifico: o modernismo, no Brasil, tem como ponto de partida a afirmação do nacional. Essa afirmação, quando bem-sucedida, significa um predomínio do herodianismo crítico ou do zelotismo ilustrado? Em outras palavras: o que é a razão antropofágica, na sua devoração crítica do legado universal? Qual seria, nesse sentido, a rubrica adequada para a postura de Oswald de Andrade e para a de Mário de Andrade - “... um tupi tangendo um alaúde”, no verso de Paulicéia desvairada, que inspirou o título do belo livro de Gilda de Mello e Souza sobre Macunat$m a$ ? Diria que Mário tende mais para um zelotismo ilustrado de altíssima envergadura reflexiva e Oswald para um intuitivo e aforismático herodianismo crítico, mas creio que se pode argumentar de forma aberta, ajustando a ambos, em distintos momentos de vida e obra, a prevalência ora da ênfase numa atitude, ora da ênfase na outra.

Prossigo com os problemas no uso destas duas categorias: Machado de Assis e Borges são predominantemente herodianos críticos, mas Guimarães Rosa, Gabriel García Márquez e Mário Vargas Llosa seriam predominantemente zelotistas ilustrados? Penso, quanto a eles, no que diz Antonio Candido sobre o regionalismo quando este deixa de ser o pitoresco e passa a funcionar como reconhecimento da realidade de um país subdesenvolvido. Um reconhecimento que, graças à metalinguagem, converte-se num super-regionalismo onde o nacional se manifesta com a imanência do universal e se incorpora, desta maneira, ao diálogo geral da literatura. Diria que eles são zelotistas quando comparados a Machado de Assis e Borges, mas herodianos quando contrastados com Rulfo.

Pois bem: feitas estas qualificações, observaria que uma das características do herodianismo crítico é o duplo compromisso com o universalismo da cultura e com a diferença nacional. Ortega y Gasset, na Espanha, é, como lembra Hélio Jaguaribe, um paradigma de herodianismo crítico, assim como Unamuno seria o do zelotismo ilustrado. Penso que Paz, à maneira de Ortega y Gasset - sobre o qual Paz, aliás, escreveu tão bem -, integra a família dos herodianos críticos. Reflete sobre a modernidade a partir do duplo compromisso com o universal e o nacional, tendo como ponto de partida a perspectiva da diferença latino-americana. Esta reflexão, em Paz, obedece a uma dialética de complementaridade, constitutiva do movimento dialógico da diferença - para voltar, Haroldo, à terminologia do seu artigo.

O primeiro livro de reflexão de Paz é O labirinto de solidão (1 a edição 1950) - uma estupenda análise sobre o que é ser mexicano. O segundo livro de Paz, nesta linha, e $O$ arco e a lira (1 $1^{\text {a }}$ edição 1956) - uma admirável reflexão sobre o fenômeno poético e o seu lugar na história universal. Esta alternância dialógica do universal e do nacional marca toda a obra de $\mathrm{Paz}$ - inclusive a sua poética, numa interação de afinidade e oposição, união e separação. Não é por acaso que os dois últimos livros em prosa de Paz continuam sendo assinalados por estas alternâncias, pois são Tiempo nublado (1983) uma importantíssima reflexão política sobre o mundo contemporâneo - e Sor Juana Inés de la Cruz (1982) - cuja figura e obra Paz vê como um emblema da contradição que se inicia no século XVII, entre a decadência da Espanha e o anúncio, no México, de uma nova civilização. 